\title{
THE LEVERHULME TRUST
}

$\mathrm{T}$ HE fifth report of the Leverhulme Trustees* covers the years $1962-64$, in which commitments totalled $£ 1,230,950$, of which $£ 591,650$ was to the universities and centres of higher education, $£ 130,950$ to learned societies and research institutions, and $£ 193,700$ to medical research; these figures compared with $£ 885,350, £ 371,150, £ 46,550$ and $£ 184,900$, respectively, in the triennium 1959-61. Among the grants to universities may be noted $£ 3,750$ to the Department of Zoology, University of Cambridge, for taxonomic work; $£ 11,000$ to the Department of Sociology, University of Essex, for a survey of journalism; $£ 1,300$ to the University of Keele for research into municipal government; and $£ 18,500$ to the University of Lancaster for research into higher education. A further $£ 3,000$ went to the University of Leeds for research posts in the history and philosophy of science, and $£ 24,000$ for the proposed diploma course in development administration for overseas students. The University of Liverpool received $£ 34,000$ for fellowships in general research; the Institute of Education, London, $£ 18,000$; the London School of Economics, $£ 12,950$ for scholarship and research awards and $£ 2,400$ towards a conference on the philosophy of science. The University of Manchester received $£ 2,700$ for a research fellowship in the Department of Chemistry on the metabolism and biosynthesis of unsaturated fatty acids, $£ 4,000$ for an investigation of income distribution in the United Kingdom before and after tax, and a final grant of $£ 6,000$ for the Jodrell Bank Experimental Station. The Department of Chemistry, University of Newcastle upon Tyne, received $£ 3,600$ for an investigation of the enzyme, catalase, in the decomposition of hydrogen peroxide, and the University of Nottingham $£ 8,900$ for a project in adult education through the medium of television. A grant of $£ 35,000$ to Queen's University, Belfast, was for staff for the School of Librarianship, while $£ \mathbf{1}, 550$ goes to the University of St, Andrews for industrial health courses at Queen's College, Dundee, and $£ 22,500$ to the University of Southampton for the Department of Econometries. Overseas grants included $£ 18,000$ for tutorial staff for University

* The Fifth Report of the Leverhulme Trustees, 1962-1964. Pp. 93. (London: The Leverhulme Trust, 3965.)
College, Dar-es-Salaam; $£ 28,000$ for Royal Society Leverhulme visiting professorships for India; $£ 24,500$ for the Inter-University Conference, Hong Kong; $£ 15,000$ to University College, Nairobi, for adult education; and $£ 18,000$ for tutorial staff at University College, Makerere.

The Association of Commonwealth Universities received $£ 6,600$ for travel grants for the ninth quinquennial conference, the British Association $£ 3,500$ for analysis of mathematics teaching projects, the British Museum £3,500 for a research fellowship on mammals, the Institute for Strategic Studies a further $£ 4,500$ for a research assistant, the Joint Mathematical Council for the United Kingdom $£ 6,000$ for research into teaching mathematics, and the Institute of Mathematics and its Application another $£ 8,000$ for the same purpose. $£ 70,000$ went to the Royal Society for Leverhulme Scholarships for young scientists, and $£ 3,000$ to the Scott Polar Research Institute for a research assistant.

Awards to schools, chiefly for scholarships, totalled $£ 36,400$; to architecture, $£ 48,600$, including $£ 9,000$ to the Royal Institute of British Architects for an industrialized building study; and miscellaneous grants included $£ 15,000$ to the Administrative Staff College, $£ 20,000$ to the Centre for Educational Television Overseas for English Language Teaching, $£ 15,000$ to Voluntary Service Overseas, and $£ 5,000$ to the Overseas Development Institute for an economic survey of Uganda. Among those for medical research may be mentioned $£ 22,500$ to the Department of Electrical Engineering, Imperial College of Science and Technology, for a one-year course for postgraduate medical students; $£ 20,000$ to the Liverpool School of Tropical Medicine for a visiting lectureship, $£ 25,000$ to the Middlesex Hospital Medical School for scholarships at the Institute of Clinical Research; $£ 32,400$ to the Eastman Dental Hospital for visiting Indian and Pakistani studentships; $£ 13,500$ to the Royal College of Surgeons for research assistantships at the Institute of Basic Medical Sciences; $£ 8,300$ to the Institute of Orthopaedics for a research fellowship in the Department of Biomechanics; and $£ 6,600$ to the Departrnent of Mental Health, University of Aberdeen.

\section{SELECTION OF CLAY BUILDING BRICKS}

$\mathrm{D}$ EFECTS in brickwork, when these occur, are not necessarily due to faulty design or construction, but often probably because the properties of the bricks used in a particular building or other project are not given enough serious consideration in the first place, relative to the proposed conditions which they are destined to withstand. For example, constructional brickwork should not, be or remain, excessively wet, since clay building bricks differ in their tolerance of exposure to wet conditions; wet brickwork lends itself to risk of sulphate attack on the mortar, to efflorescence, and to frost damage; sulphate expansion of mortar rarely occurs except in parapet and retaining walls subject to continual water infiltration; where sulphate expansion of brickwork in normal external walls does occur, this is often due to the bricks themselves containing excessive soluble sulphates, for example, potassium sulphate. This advice is among the many practical hints given in The Selection of Clay Building Bricks-1*.

- Building Research Station Dlgest (Sccond Series), No. 65 (December * Building Research Station Dlgest (Sccond Series), No. 65 (December
1965): The Selection of Clay Building Bricks-1. Pp. 4. (London: H.M.S.O., 1965): The
Criticisms are often voiced on the admittedly ugly, white, powdery growth or encrustations revealed on brickwork, especially on new buildings, to the effect that this is due to use of newly manufactured bricks, not properly kilned, or possibly not long enough 'seasoned', or to use of inferior raw materials, and so on; actually, as this pamphlet is at pains to emphasize, efflorescence is normally a temporary springtime occurrence on new brickwork and is generally harmless; it happens because very small amounts of alkali salts, usually derived from cement in the mortar, are latent to produce this blemish, given the right conditions. "Examples of destructive efflorescence, where crystallization of soluble salts causes crumbling of brick surfaces or displacement of plaster, are rare-probably rarer than they were a generation ago, to judge from enquiries received at the Building Research Station." Efflorescence can recur every spring for many years, so long as water can find ways of percolating through the brickwork; in parapet walls this often implies faulty damp-proof courses; none the less, it is on all occasions unsightly, but difficult to eradicate completely; beyond remarking that the precautions on site necessary to reduce 